\title{
Using a Virtual Platform to Teach Residents How to Respond to Bias
}

J Gen Intern Med 37(11):2871-2

DOI: $10.1007 / \mathrm{s} 11606-021-07156-y$

(C) Society of General Internal Medicine 2021

\section{INTRODUCTION}

Resident physicians frequently experience bias. ${ }^{1}$ Women residents experience patient-held bias more frequently than men, and Black, Latinx, and Asian residents experience bias more frequently than their White colleagues. ${ }^{1}$ Recurrent experiences of bias contribute to trainee burnout ${ }^{2}$ and to depressive symptoms $^{3}$; however, many residents feel inadequately trained to respond to bias. ${ }^{2}$

Microaggressions, brief statements or behaviors that communicate negative messages regarding minority group identity related to race/ethnicity, sex, gender, sexual orientation, etc., ${ }^{4}$ occur frequently in clinical settings. Because of COVID-19, in-person microaggression trainings, which provide the tools to navigate these challenging encounters, ${ }^{5}$ were suspended. We thus created a virtual microaggression training session, which we hypothesized would improve interns' ability to respond to bias directed towards themselves or colleagues.

\section{METHODS}

All 85 PGY-1 internal medicine residents participated in a 1-hlong, Zoom-based workshop. The workshop included a 20min didactic, which provided a framework for responding to microaggressions, followed by small groups (4-6 interns and 1 trained faculty facilitator) where participants applied the framework to vignettes and developed responses to experienced or observed bias. Interns were surveyed prior to and immediately after the workshop (Mentimeter.com). Respondents provided their self-identifiedrace/ethnicity and gender identity. Respondents who selected Asian, Black, Latinx, or other were categorized as non-White. Facilitators were surveyed after the workshop.

The two primary endpoints were the change in interns' comfort with responding to bias directed towards colleagues or themselves. Wilcoxon signed-rank test was used to compare pre- vs. postworkshop survey responses. MannWhitney $U$ test (Wilcoxon rank sum test) was used to assess

Received July 15, 2021

Accepted September 16, 2021

Published online October 12, 2021 between-group differences in medians (female vs. male and non-White vs. White). Data are expressed as median and $25^{\text {th }}-$ $75^{\text {th }}$ percentile. All tests were two-sided tests with $p<0.05$ considered statistically significant; there was no correction for multiple comparisons (GraphPad Prism version 9.1.0 for Windows, GraphPad Software, San Diego, CA, USA).

\section{RESULTS}

All internal medicine interns attended the workshop and completed some elements of the survey (Table 1); 88\% reported observing gender bias during residency; $72 \%$ observed racial bias. Fifty-nine percent reported personally experiencing gender bias during residency; $32 \%$ reported personally experiencing racial bias. More commonly, females experienced gender bias $(p<0.0001)$ and non-White interns experienced racial bias $(p<0.0001)$ (Table 2). Patients/families were the most common source of bias (78\%), $8 \%$ identified non-physician colleagues, and $7 \%$ identified peers, attendings, or others.

The training increased participants' comfort in responding to biased statements directed towards themselves (median score preworkshop $=3\left(25^{\text {th }}-75^{\text {th }}\right.$ percentile, $\left.3-4\right)$, median score postworkshop $=5\left(25^{\text {th }}-75^{\text {th }}\right.$ percentile, $\left.4-5\right) ; p<$ 0.0001). Similarly, after the training, participants felt more comfortable responding to bias directed towards a colleague (median score preworkshop $=5\left(25^{\text {th }}-75^{\text {th }}\right.$ percentile, $\left.4-5\right)$, median score postworkshop $=6\left(25^{\text {th }}-75^{\text {th }}\right.$ percentile, $\left.5-6\right) ; p$ $<0.0001)$. Nearly all $(95 \%)$ interns would recommend the session to a friend or colleague (Likert score of $\geq 5$ out of 10 ). Ninety-one percent of the facilitators completed the survey, and all faculty respondents endorsed the effectiveness of their training, the workshop itself, and the virtual format.

Table 1 Demographics of Participants Who Responded to Questions (All Participants) and Those Who Completed Both Preand Postworkshop Survey Questions

\begin{tabular}{lll}
\hline \hline & $\begin{array}{l}\text { All } \\
\text { participants } \\
(\boldsymbol{n}=\mathbf{8 5})\end{array}$ & $\begin{array}{l}\text { Participants who completed } \\
\text { both pre- and postworkshop } \\
\text { surveys }(\boldsymbol{n}=\mathbf{6 0})\end{array}$ \\
\hline $\begin{array}{l}\text { Gender identity } \\
\begin{array}{l}\text { Female } \\
\text { Male }\end{array}\end{array}$ & $43(51 \%))$ & $35(58 \%)$ \\
$\begin{array}{l}\text { Declined to answer } \\
\text { Race/ethnicity }\end{array}$ & $35(4 \%)$ & $25(42 \%)$ \\
$\begin{array}{l}\text { Non-White } \\
\begin{array}{l}\text { White } \\
\text { Declined to answer }\end{array}\end{array}$ & $38(45 \%)$ & 0 \\
\hline
\end{tabular}


Table 2 Observation of and Personal Experience of Gender or Racial Bias During Training

\begin{tabular}{|c|c|c|c|c|c|c|c|c|}
\hline & $\begin{array}{l}\text { Observed } \\
\text { gender bias }\end{array}$ & $p$ value $^{\dagger}$ & $\begin{array}{l}\text { Observed } \\
\text { racial bias }\end{array}$ & p value ${ }^{\dagger}$ & $\begin{array}{l}\text { Experienced } \\
\text { gender bias }\end{array}$ & p value ${ }^{\dagger}$ & $\begin{array}{l}\text { Experienced } \\
\text { racial bias }\end{array}$ & p value ${ }^{\dagger}$ \\
\hline $\begin{array}{l}\text { All } \\
n=85\end{array}$ & $75(88 \%)$ & & $61(72 \%)$ & & $50(59 \%)$ & & $27(32 \%)$ & \\
\hline $\begin{array}{l}\text { Female } \\
n=43\end{array}$ & $41(95 \%)$ & $p=0.07$ & $32(74 \%)$ & $p=0.62$ & $39(91 \%)$ & $p<0.0001^{*}$ & $15(35 \%)$ & $p=0.81$ \\
\hline $\begin{array}{l}\text { Male }^{*} \\
n=35\end{array}$ & $28(80 \%)$ & & $24(69 \%)$ & & $6(17 \%)$ & & $11(35 \%)$ & \\
\hline $\begin{array}{l}\text { Non- } \\
\text { White } \\
n=38\end{array}$ & $34(89 \%)$ & $p=0.99$ & $25(66 \%)$ & $p=0.30$ & $22(58 \%)$ & $p=0.99$ & $23(61 \%)$ & $p<0.0001^{*}$ \\
\hline $\begin{array}{l}\text { White } \\
n=37\end{array}$ & $33(89 \%)$ & & $29(78 \%)$ & & $21(57 \%)$ & & $2(5 \%)$ & \\
\hline
\end{tabular}

*Data for participants who declined to provide their gender or race are not included

ttp values reflect the differences in observed or experienced bias between female vs. male or non-White vs. White participants by Mann-Whitney test

\section{DISCUSSION}

To our knowledge, there has not been a prior report on using a virtual platform to conduct a microaggressions workshop for residents. Facilitators assessed the virtual format to be effective. Participants were similarly positive about the format and remained engaged in the small-group discussions. Importantly, the workshop improved residents' readiness to respond to bias. These data support the ongoing utilization of virtual workshops, particularly as trainee-experienced bias continues to rise. ${ }^{1}$

Limitations of this study include the small sample size, the use of a single internal medicine residency program, and survey-based outcomes.

While our workshop promotes trainee resilience in addressing microaggressions and bias, health systems should also focus on implementing policies that promote inclusion at all levels of the learning environment. ${ }^{6}$ In addition to workshops for trainees, similar training for faculty and the wider hospital community would mitigate the impacts of bias more broadly. ${ }^{6}$ This study demonstrates that the virtual format is an effective platform for conducting skill-building workshops to address microaggressions. Future studies should include using virtual platforms for faculty and staff bystander training and further evaluation of virtual versus in-person settings for these important workshops.

Gabrielle Kis Bromberg, $M D^{1,2}$

Elizabeth A. Gay, $M D^{1}$

Kelsey Hills-Dunlap, $M D^{1}$

Sherri-Ann M. Burnett-Bowie, MD, MPH ${ }^{1,2}$

${ }^{1}$ Department of Medicine, Massachusetts General Hospital,

Boston, MA, USA

${ }^{2}$ Harvard Medical School,

Boston, MA, USA

Corresponding Author: Gabrielle Kis Bromberg, MD; Department of Medicine, Massachusetts General Hospital, Boston, MA, USA (e-mail: gbromberg@mgh.harvard.edu).

\section{Declarations:}

Conflict of Interest: The authors declare that they do not have a conflict of interest.

\section{REFERENCES}

1. Fnais N, Soobiah C, Chen MH, et al. Harassment and discrimination in medical training: a systematic review and meta-analysis. Acad Med. May 2014;89(5):817-27. https://doi.org/10.1097/acm. 0000000000000200

2. Hu YY, Ellis RJ, Hewitt DB, et al. Discrimination, abuse, harassment, and burnout in surgical residency training. $N$ Engl $\mathrm{J}$ Med. 2019;381(18):1741-1752. https://doi.org/10.1056/NEJMsa 1903759

3. Anderson $\mathbf{N}$, Lett $\mathbf{E}$, Asabor EN, et al. The Association of Microaggressions with Depressive Symptoms and Institutional Satisfaction Among a National Cohort of Medical Students. J Gen Intern Med. Apr 2021. https://doi.org/10.1007/s11606-021-06786-6. Epub ahead of print.

4. Sue DW. Microaggressions in Everyday Life: Race, Gender, and Sexual Orientation. 2010. Print.

5. Fisher HN, Chatterjee $\mathbf{P}$, Shapiro J, et al. "Let's Talk About What Just Happened": a Single-Site Survey Study of a Microaggression Response Workshop for Internal Medicine Residents. J Gen Intern Med. Jan 2021;13. https://doi.org/10.1007/s11606-020-06576-6.

6. Mateo CM, Williams DR. More Than Words: AVision to Address Bias and Reduce Discrimination in the Health Professions Learning Environment. Acad Med. Dec 2020;95(12S):S169-S177. https://doi.org/10.1097/ACM. 0000000000003684.

Publisher's Note: Springer Nature remains neutral with regard to jurisdictional claims in published maps and institutional affiliations. 